\title{
Extremely cool summers in Central and Eastern Europe (1951-2010)
}

\author{
Robert Twardosz $\cdot$ Urszula Kossowska-Cezak
}

Received: 27 January 2014/Accepted: 31 August 2014/Published online: 11 September 2014

(C) The Author(s) 2014. This article is published with open access at Springerlink.com

\begin{abstract}
The paper reports on a study of extremely cool summers (ECS), a rare but significant phenomenon responsible for various adverse economic effects. These include, in particular, effects on agriculture and the tourist industry. The seasons, their spatial extent and individual characteristics were identified in Central and Eastern Europe. The research was based on average seasonal air temperatures (June to August) and the numbers of days with maximum temperatures $>25,30$ and $35^{\circ} \mathrm{C}$ and minimum temperatures $>20{ }^{\circ} \mathrm{C}$, as recorded at 59 weather stations during the period 1951-2010. An ECS was defined as having an average temperature at least 2 standard deviations $\left(t \leq t_{a v}-2 \sigma\right)$ lower than the average at a given station during the study period. ECS occurred at only 34 of the 59 stations (58\% of all stations), one or two per station, mainly in the northern part of the study area. Six such seasons were recorded by at least $5 \%$ of all stations in 1962, 1969, 1976, 1978, 1984 and 1994. The average temperature of an ECS was typically $2-3{ }^{\circ} \mathrm{C}$ lower than the long-term average. While some ECSs included an extremely cool month, most such seasons $(58 \%)$ were defined by low temperatures persisting for long periods in all summer months.
\end{abstract}

Keywords Cool summers - Temperature anomaly $\cdot$ Central Europe $\cdot$ Eastern Europe

\section{Introduction}

The occurrence of extremely warm or cool months and seasons is a known feature of the temperate climate zone in Europe where the weather is influenced by a highly variable

R. Twardosz $(\bowtie)$

Department of Climatology, Jagiellonian University, ul. Gronostajowa 7, 30-387 Kraków, Poland e-mail: r.twardosz@uj.edu.pl

U. Kossowska-Cezak

Department of Climatology, Faculty of Geography and Regional Studies, Warsaw University, ul. Krakowskie Przedmieście 30, 00-927 Warsaw, Poland 
atmospheric circulation. Exceptionally warm months and seasons have attracted much research, especially in recent years when they tended to occur more frequently than 30-40 years ago (Kossowska-Cezak and Twardosz 2012a, b; Twardosz and KossowskaCezak 2012, 2012a, b). This focus seems more than justified in view of the fact that such warm conditions cause adverse biometeorological conditions, droughts and other phenomena, such as forest fires.

The situation is quite the opposite with extremely cool summers (ECS) and their presence in climatological research. The studies available indicate a higher frequency of occurrence of such seasons in the nineteenth century and early twentieth centuries (Gerstengarbe and Werner 1992; Filipiuk and Kaszewski 2000; Elizbarashvili et al. 2007). Two particular seasons attracted particular attention, i.e. the cool and wet summer of 1816 (e.g. Piervitali et al. 1997; Trigo et al. 2009) and the summer of 1913, the coolest summer in Central Europe during the 1871-1990 period (Filipiuk and Kaszewski 2000). Reasons leading to this relative neglect of ECS include their lower frequency of occurrence (or the complete lack of such seasons, such as has recently been the case) and their less severe impacts on nature, biometeorological conditions and the economy than those of extremely hot summers. This does not, however, mean that ECS have no adverse effects. Persistent low temperatures in summer are felt in agriculture in the form of smaller and delayed harvests of inferior quality produce, as reported for example in the cold and wet summer of 1816 (Trigo et al. 2009). Tourism is affected particularly by a combination of wet and cold, which not only diminishes comfort, but also the safety of holidaymakers (de Freitas 2003; Scott and Lemieux 2010). Cold summers in Central Europe are mostly a result of the advection of fresh maritime air from the Atlantic Ocean that is often accompanied by intensive rainfall (Kossowska-Cezak 1997; Kuziemska 1975; Jaagus 2006; Twardosz et al. 2011). This means that during these cool periods, excessive rainfall is a greater threat to human life and activity than the low temperature itself.

Many researchers have demonstrated (Piervitali et al. 1997; Slonosky et al. 2001; Bardin 2007; Zveryaev 2007; Sidorenkov and Orlov 2008; Anisimov et al. 2011; Twardosz et al. 2011) that air temperature and precipitation depended on atmospheric circulation. Cool summers in Central Europe coincide with a high frequency of cyclonic circulation from the west and north, which is normally accompanied by greater cloud cover than in anticyclonic situations (Kossowska-Cezak 1997; Twardosz et al. 2011). In Eastern Europe, summer cold waves are caused by similar types of circulation, which are linked specifically to the so-called diving Scandinavian cyclones (Elizbarashvili et al. 2007; Isayev and Sherstyukov 2008).

The literature also mentions volcanic causes of cool summers, such as in the case of the anomalously low temperatures in the summer of 1816 in Europe after the eruption of Tambora in 1815 (Piervitali et al. 1997; Trigo et al. (2009). That exceptionally cold summer of 1816 was also associated with causes linked to circulation.

The distribution of surface pressure field was similar to a dipole with a low over Europe and a high pressure over the North Atlantic and Iceland. According to Piervitali et al. (1997), this pattern could correspond to frequent blocking situations with a cold airflow coming from high latitudes towards the Central-Southern regions of Europe.

The study is intended to find out the frequency and spatial coverage of extremely cool summer seasons in Central and Eastern Europe and the change of this frequency from the mid-twentieth century in the wake of progressive climate warming. The paper links in with earlier research by the authors (Kossowska-Cezak and Twardosz 2012, 2013; Twardosz and Kossowska-Cezak, 2013a, b) on extremely hot summers. 


\section{Data and methods}

The study is based on average seasonal air temperatures (June to August) during the period 1951-2010, as recorded at 59 weather stations scattered over an area ranging from $45^{\circ} \mathrm{N}$ to $65^{\circ} \mathrm{N}$ and from $15^{\circ} \mathrm{E}$ to $60^{\circ} \mathrm{E}$ (excluding the Scandinavian Peninsula) (Table 1). Other data used included average monthly maximum and minimum temperatures and the numbers of days with a maximum temperature $>25{ }^{\circ} \mathrm{C}$ (summer days), $>30{ }^{\circ} \mathrm{C}$ (hot days) and $>35^{\circ} \mathrm{C}$ (very hot days), as well as with a minimum temperature $>20{ }^{\circ} \mathrm{C}$ (tropical nights). This choice of threshold values provides good insight into summer temperatures. They are broadly used to define both extremely cool and extremely hot summer seasons (Gerstengarbe and Werner 1992), which makes comparison between these two extreme types of season possible. Low numbers of such days would indicate increased cold stress, while high numbers would point to increased heat stress.

The bulk of the data comes from the European Climate Assessment \& Dataset (ECA\&D) (www.eca.knmi.nl). This database normally verifies all datasets for uniformity. Gaps found in the summer average temperature data, which were few and limited to certain Russian stations, have been filled in using data from adjacent stations through correlation.

An overwhelming majority of the stations included in the study are located in lowlands. There were 49 stations below an altitude of $200 \mathrm{~m}, 7$ stations between 200 and $300 \mathrm{~m}$ and only 3 stations lying above 300 m (L'viv 323 m, Praha 365 m and Cluj $411 \mathrm{~m}$ ). Astrachan' is in a depression $(-23 \mathrm{~m})$.

The stations were numbered in latitudinal belts of $5^{\circ}$ starting from the north. The belt above $60^{\circ} \mathrm{N}$ has 8 stations $(1-8), 55^{\circ}-60^{\circ} \mathrm{N}-13$ stations $(9-21), 50^{\circ}-55^{\circ} \mathrm{N}-22$ stations (22-43) and below $50^{\circ} \mathrm{N}-16$ stations (44-59) (Table 1).

Since the measure of the scale of a thermal anomaly is the deviation of the season's average temperature from the appropriate long-term average, long-term average temperatures (1951-2010) were taken as the departure point for the identification of cases for this study. Extremely cool months and seasons were defined as those having an average air temperature at least two standard deviations $\left(\mathrm{t} \leq \mathrm{t}_{\mathrm{av}}-2 \sigma\right)$ lower than the long-term average (1951-2010) at a given station. The criterion has been adopted to mirror that used for exceptionally warm months and seasons $\left(t \geq t_{a v} .+2 \sigma\right)$ (Twardosz and KossowskaCezak, 2012, 2013a, b). By referencing average thermal conditions in defining thermally anomalous periods, the study managed to take into account both the concept of a thermal anomaly as it was established in climatology (International Meteorological Vocabulary 1992) and the actual thermal conditions, to which the populations of the various European climatic regions were acclimatised.

The paper includes a calendar of extremely cool summers, including their spatial extent, thermal characteristics and a comparison of their frequency and extent with those of exceptionally hot summers (Kossowska-Cezak and Twardosz 2012, 2013a, b). A number of extremely cool months with a particularly wide coverage area were also briefly discussed.

\section{General characteristics of occurrence of extremely cool summers (ECS)}

During the study period, there were only nine summers in Central and Eastern Europe during which at least one station recorded an average summer temperature that met the requirement $\mathrm{t} \leq \mathrm{t}_{\mathrm{av}}-2 \sigma$. These ECSs covered areas of different sizes, from one (1993, Daugavpils) or two stations (Jyvaskyla and Tallinn in 1987, Ivdel' and Aktobe in 1992) to 
Table 1 List of weather stations included in the study (station names after CLINO, WMO 1996); the locations of the stations are shown in Fig. 1

\begin{tabular}{|c|c|c|c|c|c|c|c|c|}
\hline \multicolumn{2}{|c|}{ Station } & \multirow[t]{2}{*}{ WMO no } & \multicolumn{2}{|c|}{ Station } & \multirow[t]{2}{*}{ WMO no } & \multicolumn{2}{|c|}{ Station } & \multirow[t]{2}{*}{ WMO no } \\
\hline No & Name & & No & Name & & No & Name & \\
\hline 1 & Vaasa & 02911 & 21 & Ekaterinburg & 28440 & 41 & Orenburg & 35121 \\
\hline 2 & Jyvaskyla & 02935 & 22 & Berlin & 10381 & 42 & Ufa & 28722 \\
\hline 3 & Petrozavodsk & 22820 & 23 & Praha & 11518 & 43 & Aktobe & 35229 \\
\hline 4 & Arhangel'sk & 22550 & 24 & Poznan & 12330 & 44 & Zagreb & 14236 \\
\hline 5 & Kotlas & 22887 & 25 & Krakow & 12566 & 45 & Wien & 11035 \\
\hline 6 & Syktyvar & 23804 & 26 & Kaliningrad & 26702 & 46 & Budapest & 12843 \\
\hline 7 & Pecora & 23418 & 27 & Warszawa & 12375 & 47 & Beograd & 13274 \\
\hline 8 & Ivdel' & 23921 & 28 & Brest & 33008 & 48 & Debrecen & 12882 \\
\hline 9 & Riga & 26422 & 29 & Kaunas & 26629 & 49 & Cluj & 15120 \\
\hline 10 & Tallinn & 26038 & 30 & Minsk & 26850 & 50 & L'viv & 33393 \\
\hline 11 & Daugavpils & 26544 & 31 & Vasilevici & 33038 & 51 & Chernivtsi & 33658 \\
\hline 12 & Tartu & 26242 & 32 & Kyiv & 33345 & 52 & Bucuresti & 15420 \\
\hline 13 & St. Petersburg & 26063 & 33 & Smolensk & 26781 & 53 & Chrisinau & 33815 \\
\hline 14 & Moskva & 27612 & 34 & Kursk & 34009 & 54 & Sulina & 15360 \\
\hline 15 & Vologda & 27037 & 35 & Voronez & 34122 & 55 & Odesa & 33837 \\
\hline 16 & Kostroma & 27333 & 36 & Tambov & 27947 & 56 & Kharkiv & 34300 \\
\hline 17 & Niznij Novgorod & 27553 & 37 & Saratov & 34172 & 57 & Luhans'k & 34523 \\
\hline 18 & Kazan’ & 27595 & 38 & Aleksandrov-Gaj & 34391 & 58 & Astrachan' & 34880 \\
\hline 19 & Kirov & 27199 & 39 & Samara & 27995 & 59 & Atyrau & 35700 \\
\hline 20 & Perm & 28224 & 40 & Ural'sk & 35108 & & & \\
\hline
\end{tabular}

11-13 stations. The 3 years with very small-ranging ECSs were excluded from further study, as they failed to clear a $5 \%$ threshold of the number of stations (1-2 stations). The other six ECSs are listed in Table 2.

Extremely cool summers were recorded at only 34 of the 59 stations in the following distinct areas: (1) in the north of the study area reaching the furthest south between the centre of the area and eastern Ukraine (Central Russian Upland); (2) the mountains and uplands of the southeast from the Ore Mountains and Sudeten Mountains along the Carpathian Mountains; and (3) along the lower Volga river and the Russian Kazakh border (Fig. 1). These areas had one or two ECS during the 60-year study period, and only Ivdel' in the northeast had three (but there were no ECS in Pecora to the north of Ivdel', just as no ECS were recorded in Vologda).

The frequency of occurrence of ECSs was not stable in time (Table 3). There were no incidences during 1951-1960 (nor were there any exceptionally hot summers during that decade), then there were two ECS per decade in 1961-1970 and 1971-1980, followed by one each in 1981-1990 and 1991-2000, and again no exceptionally cool summers in the twenty-first century. Thus, there was an increase in the frequency of exceptionally hot summers and a decrease in the frequency of extremely cool summers, although the latter effect was less pronounced due to the lower overall frequency of ECSs. 
Table 2 Extremely cool summers (ECS) in Central and Eastern Europe (1951-2010)

\begin{tabular}{lcll}
\hline Year & $\begin{array}{l}\text { Number of } \\
\text { stations }\end{array}$ & Stations (numbers as in Table 1) & $\begin{array}{l}\text { Exceptionally cool } \\
\text { month during ECS }\end{array}$ \\
\hline 1962 & 11 & $(2),(3), 9,10,(11), 12,(13),(14),(15),(16),(26),(33)$ & June \\
1969 & 4 & $4,6,8,20$ & June \\
1976 & 8 & $(3), 13,(14),(35),(36), 51,52,(56)$ & August \\
1978 & 13 & $(5),(6),(8),(19),(20),(23),(25), 38,46,(48),(49),(50), 58$ & June \\
1984 & 4 & $49,(50), 52,(53)$ & July \\
1994 & 3 & $40,41,43$ & July \\
\hline
\end{tabular}

A station number in brackets means that at that station no month qualifies as an ECM

A comparison of the frequency and extent of ECSs and exceptionally hot summers (EHSs) during the study period demonstrates (Twardosz and Kossowska-Cezak 2012, $2013 \mathrm{a}, \mathrm{b})$ that the ECSs occurred with $50 \%$ of the frequency of the EHSs. Indeed, there were six ECSs covering at least three stations each (5\%), as opposed to 12 EHSs. Also ECSs covered smaller areas: the largest covered 13 stations (1978) while the largest EHS covered 39 stations (2010). Additionally, a clear majority of all EHSs included an exceptionally hot month (EHM) with only $8 \%$ of EHSs without one, while there were $58 \%$ of ECSs without an extremely cool month (ECM) (See: Table 2 for station numbers given in brackets).

An ECS without an ECM means that none of the summer months that year had a sufficiently great negative anomaly of air temperature $(-\Delta t)$ to influence the thermal character of the entire season. Instead, the summer would achieve ECS status through the adding up of relatively small negative anomalies in all three of its months.

To explain the causes of the differences between the frequencies of EHSs and ECSs, their spatial coverage and thermal characteristics, one should look for patterns in the longterm variability of average air temperature values in summer (June-August) in the study area. The temperature varied widely from year to year, but at a clear majority of the stations (51 of 59) the greatest positive anomaly $(+\Delta t)$ was greater than the greatest negative anomaly $(-\Delta t)$. While the positive and negative anomalies at most of the stations typically ranged between $2.1{ }^{\circ} \mathrm{C}$ and $3.0{ }^{\circ} \mathrm{C}$, negative anomalies exceeded this $3.0^{\circ} \mathrm{C}$ at only two stations ( $3 \%$ ), while positive anomalies did that at 32 stations $(58 \%)$, including by $5.1-6.0{ }^{\circ} \mathrm{C}$ at five of them (Table 4 ). This means that the statistical distribution of the average air temperature in the summer is asymmetrical with a sporadic occurrence of values considerably exceeding the long-term average (positively skewed).

The strength of this asymmetry varies within the study area (Fig. 2). Along the northwestern and northern edges (Jyvaskyla, Arhangel'sk, Pecora and Ivdel') the distribution is nearly symmetrical, as the greatest $-\Delta t$ and $+\Delta t$ achieve similar values. From there, the asymmetry increases southwards (Odesa) and eastwards (Atyrau and other stations), but is most marked in the central part of European Russia (Kursk) (Fig. 3).

This means that the summer air temperature in Central and Eastern Europe can considerably exceed the long-term average if the conditions are right, i.e. there is a strong advection of hot air from the south or southeast and great insolation. When cold air arrives from the north or northwest and strong cloud cover reduces insolation, the temperature remains below the long-term average. Indeed, the increase in temperature during the summer is greatly diminished, but this diminishing is dampened by the length of the 


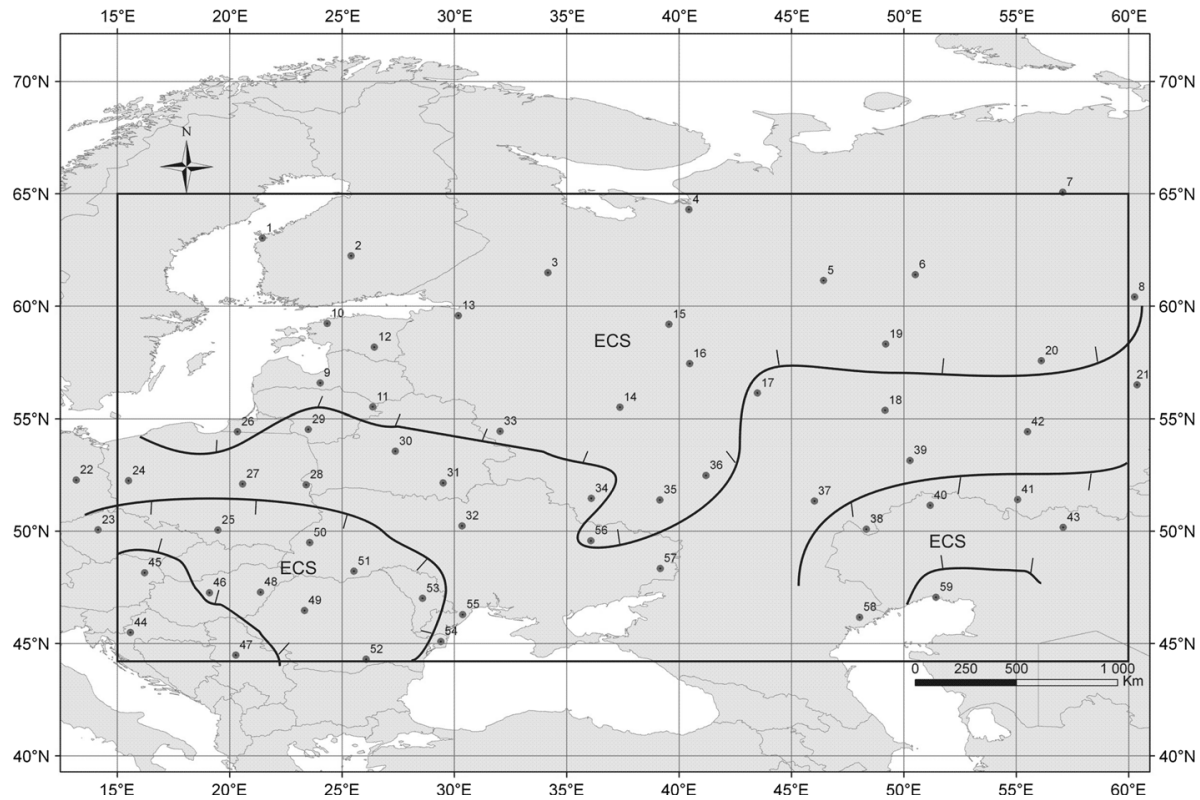

Fig. 1 Areas of occurrence of ECS summers (numbers denote stations as listed in Table 1)

Table 3 Numbers of EHS and ECS in individual decades of the period 1951-2010 in Central and Eastern Europe

\begin{tabular}{lllllllr}
\hline & $1951-1960$ & $1961-1970$ & $1971-1980$ & $1981-1990$ & $1991-2000$ & $2001-2010$ & $\Sigma$ \\
\hline EHS & 1 & - & 2 & 2 & 5 & 5 & 15 \\
ECS & - & 2 & 2 & 2 & 3 & - & 9 \\
\hline
\end{tabular}

summer day and the high zenith position of the sun during this season. There is clear corroboration for this effect of day length and sun altitude by the spatial variability of the maximum positive temperature anomaly $+\Delta t$ in summer within the area.

\section{Location and thermal characteristics of ECS}

The first decade of the study period was characterised by relatively low fluctuation of air temperature in Central and Eastern Europe. No ECS was recorded and there was only one EHS, which was only recorded at a single station (Kossowska-Cezak and Twardosz 2012, 2013a, b). There were only two ECMs.

There were two ECSs during each of the following two decades. During the 1960s, exceptionally cool summers were observed in 1962 and 1969.

The ECS of 1962 was one of the two most widespread ones, as it covered 11 stations stretching from Finland, to lands east of the Baltic Sea and to north-western Russia with Smolensk, Moscow and Kostroma (Fig. 4). This was also the coolest summer of the 60 -year period. The average temperature was lower than the respective long-term average 
by $2-3{ }^{\circ} \mathrm{C}$ (average temperature anomaly $\Delta t$ from -2.0 to $3.7^{\circ} \mathrm{C}$ ). All months of the summer were cool, including an ECM in June in Latvia and Estonia. Elsewhere June or July was the coolest of the study period, but not to the point of being ECM. There were no hot days or tropical nights anywhere but only individual summer days (e.g. two in Moscow compared to 27 on average; and three in St. Petersburg compared to 16; Table 5). During this summer, especially in June and July, northern circulation clearly dominated (Sidorenkov and Orlov 2008).

The ECS of 1969 covered north-eastern Russia from the White Sea to Ivdel' and Perm, but excluding Pecora (where it was still one of the two coolest summers) (Fig. 4). At most of the stations, this was the coolest summer of the study period (Table 5) and June was an ECM. In June, the anomaly achieved a record $5.5^{\circ} \mathrm{C}$ and $5.3{ }^{\circ} \mathrm{C}$, respectively, at Syktyvar and Pecora. The average temperature anomaly $(\Delta t)$ of this ECS ranged from $-2.4^{\circ} \mathrm{C}$ to $-2.9^{\circ} \mathrm{C}$. Summer days were sporadic ( 7 in Arhangel'sk and 8 in Perm, compared to 15 and 29 on average, respectively).

The 1970s were marked by two vast ECSs and two ECMs with exceptionally low temperatures and also a large coverage. The ECS of 1976 was recorded in two distinct areas. The larger of them was a long "tongue" stretching from eastern Finland and northeastern Russia, to St. Petersburg, Moscow, Tambov and to Kharkiv in north-eastern Ukraine (Fig. 4). The other one was smaller and covered some of the south-western edge of Ukraine and central Romania up to its southern border. The temperature anomalies of both ECSs were similar at $-2.1{ }^{\circ} \mathrm{C}$ to $-3.1{ }^{\circ} \mathrm{C}$. The $-3.1{ }^{\circ} \mathrm{C}$ anomaly at Voronez and Tambov was the greatest negative summer anomaly in this study. At nearly all stations of the two areas, this was the coolest summer of the study period (Table 5). All summer months were cool, including an ECM in June in St. Petersburg and August in Chernivtsi and Bucuresti. At each of the stations one of the months, mostly August was the coolest of the study period. Summer days were observed everywhere, but were much fewer than on average (by ca. 1/3rd, e.g. 5 in St. Petersburg, 16 in Tambov, compared to an average of 16 and 45, respectively). Hot days were only recorded in Bucuresti (6 vs. 34 on average).

As has already been mentioned, August was a very cool month. Indeed, it was an ECM from the south-western tip of the area all the way to the Black Sea coast. It was the coolest August of the study period with an anomaly ranging from $-3.1{ }^{\circ} \mathrm{C}$ to $-4.0{ }^{\circ} \mathrm{C}$. Summer days were rare and Odesa experienced none (19 on average), marking it as the only August without summer days during the 60 years and one of two such months overall.

The summer of 1978 was cool across the entire area of Central and Eastern Europe, but was classified as an ECS $\left(\mathrm{t} \leq \mathrm{t}_{\mathrm{av}}-2 \sigma\right)$ in three distinct areas: in the southwest, excluding its south-western tip; in the northeast, excluding Pecora; and along the lower Volga river valley (Fig. 5), covering the largest number of 13 stations in the study period. Throughout the rest of the study area, the anomaly was just short of the criterion adopted. At nearly all the stations, this was the coolest summer of the period (Table 5) with an anomaly $\Delta t$ from $-1.9{ }^{\circ} \mathrm{C}$ to $-2.9{ }^{\circ} \mathrm{C}$. At some of the stations, June or July was an ECM. Summer days were observed at all stations, but less often than normally (e.g. 13 vs. 29 in Perm, 10 vs. 28 in L'viv and 73 vs. 85 in Astrachan'). Hot days were only recorded in Astrachan' (29 vs. 52), as were tropical nights (11 vs. 26). Based on an analysis of the Met Office synoptic maps of Europe, it was established that the entire summer of 1978 was dominated by western and northern circulations with a high frequency of cyclonic situations.

During the 1970s, the ECM in July 1979 covered a particularly large area. It included Lithuania, Latvia, eastern Poland and Belarus, western Ukraine and Romania. This was the coolest July of the study period with an anomaly ranging from $-2.7^{\circ} \mathrm{C}$ to $-4.0{ }^{\circ} \mathrm{C}$. 
Table 4 Number of stations with the greatest temperature anomalies $(\Delta t)$ of various magnitudes in summer (June-August) in Central and Eastern Europe (1951-2010)

\begin{tabular}{lllllll}
\hline Temperature anomaly $\Delta t$ & \multicolumn{6}{l}{ Greatest anomaly I $\Delta t \mid\left({ }^{\circ} \mathrm{C}\right)$} \\
\cline { 2 - 7 } & $0.0-2.0$ & $2.1-3.0$ & $3.1-4.0$ & $4.1-5.0$ & $5.1-6.0$ & $\Sigma$ \\
\hline$-\Delta t$ & & & & & & \\
Number of stations & 13 & 44 & 2 & - & - & 59 \\
$\%$ & 22.0 & 74.6 & 3.4 & - & - & $100 \%$ \\
$+\Delta t$ & 1 & 26 & 17 & 10 & 5 & 59 \\
Number of stations & 1 & 44.0 & 28.8 & 17.0 & 8.5 & $100 \%$ \\
$\%$ & 1.7 & & & & & \\
\hline
\end{tabular}

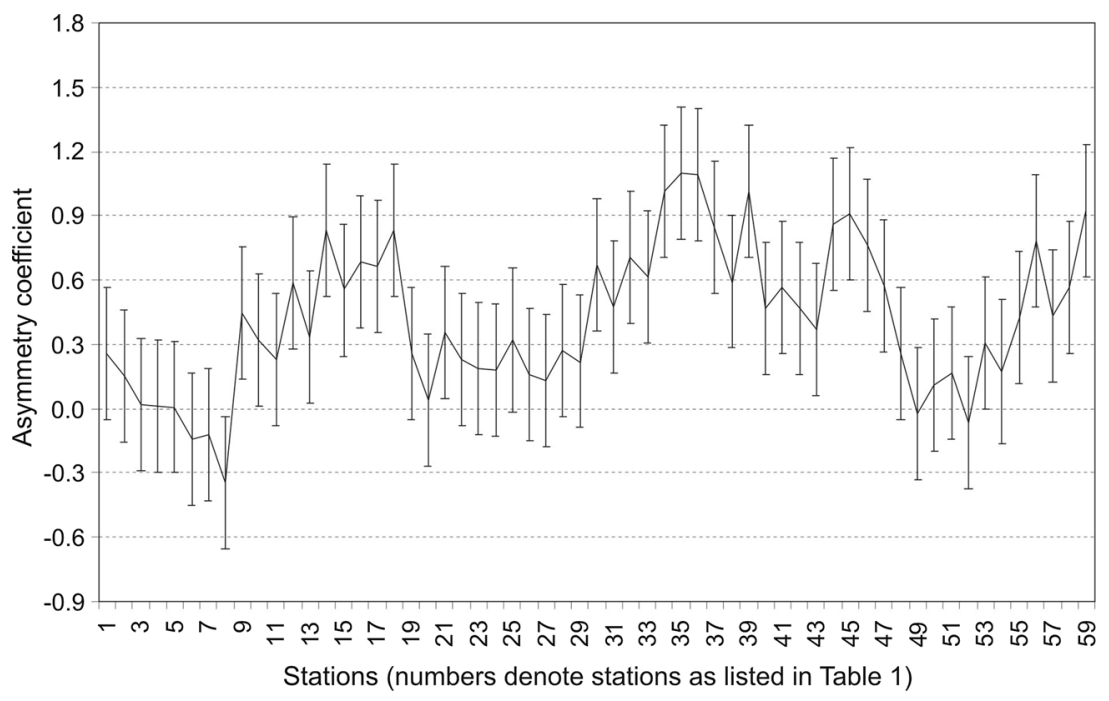

Fig. 2 Asymmetry coefficient of average temperature values in summer and standard error of the asymmetry

Summer days were only recorded in the south of the area and two hot days occurred in Bucuresti (14 on average).

During the 1980s, there was just one ECS that cleared the $5 \%$ threshold. It was limited to central and eastern Romania and an adjacent eastern tip of the Ukraine, as well as Moldova. The $\Delta t$ ranged from $-2.1{ }^{\circ} \mathrm{C}$ to $-2.3{ }^{\circ} \mathrm{C}$. June or July achieved the status of ECM at some of the stations. Both hot and, in the far southern section of the area, very hot days were recorded, but less frequently than on average (10 hot days in Bucuresti compared to 34 on average, see Table 4).

The last decade of the twentieth century also had one ECS clearing the $5 \%$ threshold in 1994. It covered an area including the three south-eastern stations of Ural'sk, Orenburg and Aktobe. This was the coolest summer of the study period at these stations $\left(\Delta t-2.5^{\circ} \mathrm{C}\right.$ to $-2.8{ }^{\circ} \mathrm{C}$ ) with July being the coolest ECM of the period. Summer and hot days were recorded, but much less frequently than on average (35 and 5 vs. 65 and 30 in Orenburg; Table 5). 


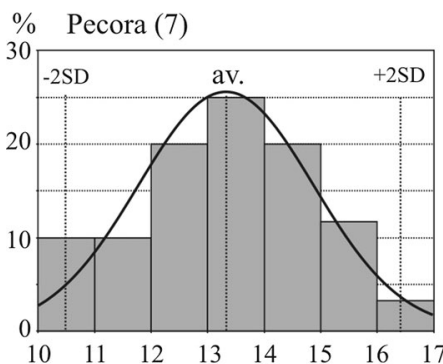

$\mathrm{Min}=10.3^{\circ} \mathrm{C} \mathrm{Av} .=13.3^{\circ} \mathrm{C}$ Max. $=16.3^{\circ} \mathrm{C}$ Asymmetry coefficient $=-0.120$

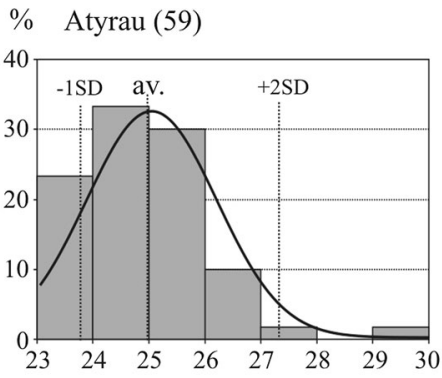

Min. $=23.2^{\circ} \mathrm{C} \mathrm{Av} .=25.0^{\circ} \mathrm{C}$ Max. $=29.4^{\circ} \mathrm{C}$

Asymmetry coefficient $=0.926$

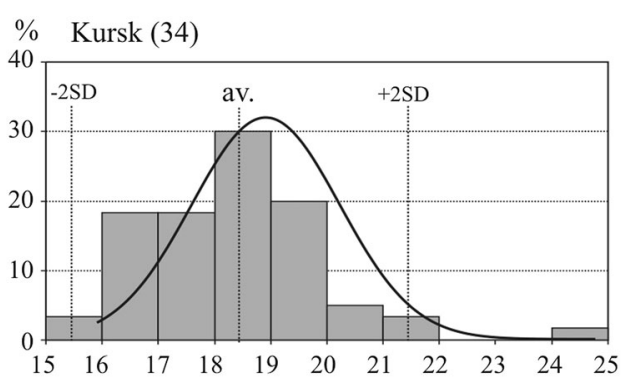

Min. $=15.7^{\circ} \mathrm{C} \quad$ Av $=18.4^{\circ} \mathrm{C} \quad$ Max. $=24.4^{\circ} \mathrm{C}$

Asymmetry coefficient $=1.02$

Fig. 3 Frequency (\%) of average temperature values in summer at selected stations

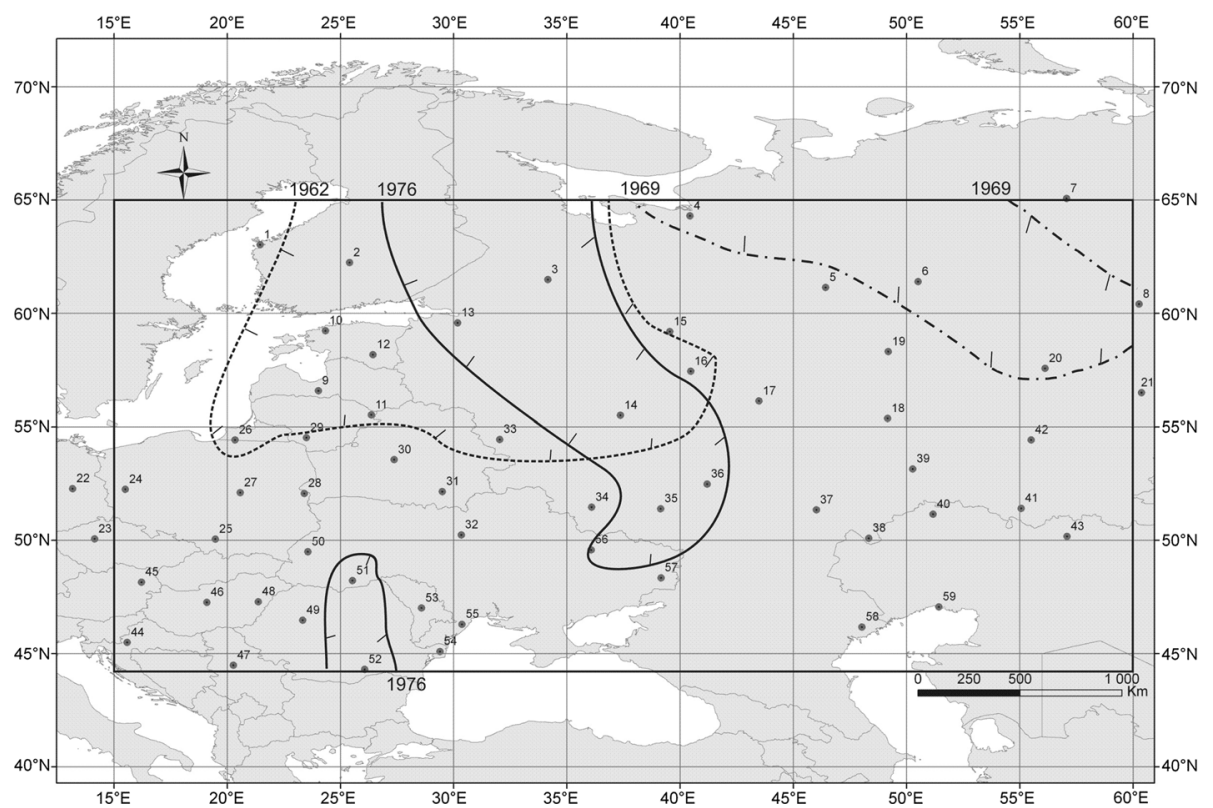

Fig. 4 ECS coverage in 1962, 1969 and 1976 
Table 5 Thermal characteristics of the summer of 1962, 1969, 1976, 1978, 1984 and 1994 (1) and longterm average (1951-2010) (2)

\begin{tabular}{|c|c|c|c|c|c|c|c|c|c|}
\hline \multicolumn{2}{|c|}{ Station } & \multicolumn{4}{|c|}{ Seasonal average air temperature $\left({ }^{\circ} \mathrm{C}\right)$} & \multicolumn{4}{|c|}{ Number of days with temperature } \\
\hline \multirow[b]{2}{*}{ No } & \multirow[b]{2}{*}{ Name } & & \multirow[b]{2}{*}{ Av. } & \multirow[b]{2}{*}{ Max } & \multirow[b]{2}{*}{ Min } & \multicolumn{3}{|l|}{$\mathrm{T}_{\max }$} & \multirow{2}{*}{$\begin{array}{l}\mathrm{T}_{\min } \\
>20^{\circ} \mathrm{C}\end{array}$} \\
\hline & & & & & & $>25^{\circ} \mathrm{C}$ & $>30{ }^{\circ} \mathrm{C}$ & $>35^{\circ} \mathrm{C}$ & \\
\hline \multicolumn{10}{|c|}{1962} \\
\hline \multirow[t]{2}{*}{2} & Jyvaskyla & 1 & $12.2^{\mathrm{a}}$ & $16.6^{\mathrm{a}}$ & 7.7 & - & - & - & - \\
\hline & & 2 & 14.6 & 19.8 & 9.1 & 12.0 & 0.4 & - & 0.0 \\
\hline \multirow[t]{2}{*}{9} & Riga & 1 & $13.9^{\mathrm{a}}$ & $18.3^{\mathrm{a}}$ & 9.4 & 1 & - & - & - \\
\hline & & 2 & 16.6 & 21.2 & 11.0 & 17.2 & 1.9 & - & 0.6 \\
\hline \multirow[t]{2}{*}{13} & St. Petersburg & 1 & $14.2^{\mathrm{a}}$ & 18.1 & $10.7^{\mathrm{a}}$ & 3 & - & - & - \\
\hline & & 2 & 16.8 & 21.1 & 12.9 & 16.3 & 1.7 & 0.0 & 1.2 \\
\hline \multirow[t]{2}{*}{14} & Moskva & 1 & 14.9 & $19.2^{\mathrm{a}}$ & 10.9 & 2 & - & - & - \\
\hline & & 2 & 17.5 & 22.5 & 12.6 & 26.8 & 4.3 & 0.3 & 1.2 \\
\hline \multicolumn{10}{|c|}{1969} \\
\hline \multirow[t]{2}{*}{4} & Arhangel'sk & 1 & $11.5^{\mathrm{a}}$ & 17.3 & $6.4^{\mathrm{a}}$ & 7 & 1 & - & - \\
\hline & & 2 & 14.1 & 19.4 & 9.4 & 14.7 & 1.4 & - & 0.4 \\
\hline \multirow[t]{2}{*}{20} & Perm & 1 & $13.8^{\mathrm{a}}$ & 19.3 & $9.5^{\mathrm{a}}$ & 8 & - & - & - \\
\hline & & 2 & 16.6 & 22.1 & 11.4 & 28.6 & 5.3 & 0.1 & 0.7 \\
\hline \multicolumn{10}{|c|}{1976} \\
\hline \multirow[t]{2}{*}{13} & St. Petersburg & 1 & 14.3 & $17.9^{\mathrm{a}}$ & 11.1 & 5 & - & - & 1 \\
\hline & & 2 & 16.8 & 21.1 & 12.9 & 16.3 & 1.7 & 0.0 & 1.2 \\
\hline \multirow[t]{2}{*}{14} & Moskva & 1 & $14.8^{\mathrm{a}}$ & 19.4 & $10.6^{\mathrm{a}}$ & 8 & - & - & - \\
\hline & & 2 & 17.5 & 22.5 & 12.6 & 26.8 & 4.3 & 0.3 & 1.2 \\
\hline \multirow[t]{2}{*}{52} & Bucuresti & 1 & $19.2^{\mathrm{a}}$ & $25.5^{\mathrm{a}}$ & $13.0^{\mathrm{a}}$ & 50 & 6 & - & - \\
\hline & & 2 & 21.6 & 28.7 & 14.8 & 75.9 & 34.1 & 4.0 & 1.7 \\
\hline \multirow[t]{2}{*}{56} & Kharkiv & 1 & $17.1^{\mathrm{a}}$ & $21.9^{\mathrm{a}}$ & $12.6^{\mathrm{a}}$ & 13 & - & - & - \\
\hline & & 2 & 20.1 & 25.5 & 14.7 & 49.6 & 15.1 & 1.6 & 4.3 \\
\hline 197 & & & & & & & & & \\
\hline 5 & Kotlas & 1 & $12.8^{\mathrm{a}}$ & $18.0^{\mathrm{a}}$ & 8.3 & 8 & 1 & - & - \\
\hline & & 2 & 15.5 & 21.2 & 10.0 & 22.9 & 3.4 & 0.0 & 0.2 \\
\hline 20 & Perm & 1 & 14.0 & $19.1^{\mathrm{a}}$ & 9.6 & 13 & - & - & 1 \\
\hline & & 2 & 16.6 & 22.1 & 11.4 & 28.6 & 5.3 & 0.1 & 0.7 \\
\hline 25 & Krakow & 1 & $15.4^{\mathrm{a}}$ & 22.0 & 11.2 & 24 & 1 & - & - \\
\hline & & 2 & 17.5 & 23.9 & 13.0 & 33.8 & 7.5 & 0.8 & 1.0 \\
\hline 50 & L'viv & 1 & 15.4 & 20.9 & 10.6 & 10 & - & - & - \\
\hline & & 2 & 17.3 & 22.7 & 12.3 & 27.8 & 2.9 & 0.0 & 0.1 \\
\hline 58 & Astrachan' & 1 & $21.9^{\mathrm{a}}$ & $28.1^{\mathrm{a}}$ & 16.6 & 73 & 29 & - & 11 \\
\hline & & 2 & 24.1 & 30.4 & 18.1 & 85.2 & 51.8 & 9.5 & 25.8 \\
\hline 198 & & & & & & & & & \\
\hline 50 & L’viv & 1 & $15.2^{\mathrm{a}}$ & 20.9 & $10.3^{\mathrm{a}}$ & 18 & - & - & - \\
\hline & & 2 & 17.3 & 22.7 & 12.3 & 27.8 & 2,9 & 0,0 & 0,1 \\
\hline 52 & Bucuresti & 1 & 19.3 & 26.0 & $13.0^{\mathrm{a}}$ & 56 & 10 & - & - \\
\hline & & 2 & 21.6 & 28.7 & 14.8 & 75.9 & 34.1 & 4.0 & 1.7 \\
\hline
\end{tabular}


Table 5 continued

\begin{tabular}{|c|c|c|c|c|c|c|c|c|c|}
\hline \multirow{2}{*}{\multicolumn{2}{|c|}{ Station }} & \multirow{2}{*}{\multicolumn{4}{|c|}{ Seasonal average air temperature $\left({ }^{\circ} \mathrm{C}\right)$}} & \multicolumn{4}{|c|}{ Number of days with temperature } \\
\hline & & & & & & \multicolumn{3}{|l|}{$\mathrm{T}_{\max }$} & \multirow{2}{*}{$\begin{array}{l}\mathrm{T}_{\min } \\
>20^{\circ} \mathrm{C}\end{array}$} \\
\hline No & \multicolumn{2}{|l|}{ Name } & Av. & $\operatorname{Max}$ & Min & $>25{ }^{\circ} \mathrm{C}$ & $>30{ }^{\circ} \mathrm{C}$ & $>35^{\circ} \mathrm{C}$ & \\
\hline \multicolumn{10}{|c|}{1994} \\
\hline \multirow[t]{2}{*}{41} & Orenburg & 1 & $18.0^{\mathrm{a}}$ & $24.0^{\mathrm{a}}$ & 12.7 & 35 & 5 & - & - \\
\hline & & 2 & 20.8 & 27.7 & 14.1 & 64.8 & 30.4 & 6.0 & 5.2 \\
\hline
\end{tabular}

a Lowest in 60 years

During the first decade of the twenty-first century, there were no ECSs in the area and even an ECM was very rare (2, exactly the same as in the 1990s). However, June 2003 was classified as an ECM, and it was the most widespread ECM of the entire study period. It stretched from the White Sea coast towards the southeast through Moscow and Niznij Novgorod to western Kazakhstan and was the coolest June of the study period in the area. The average temperature was lower than the long-term average by between $3.7^{\circ} \mathrm{C}$ and $5.0{ }^{\circ} \mathrm{C}$. The $-5^{\circ} \mathrm{C}$ anomaly of the average monthly temperature in Ural'sk was among the greatest anomalies across the period. (There were only seven cases of an anomaly equal to or greater than $-5{ }^{\circ} \mathrm{C}$ among the 117 cases in the study; the greatest value of $-5.7{ }^{\circ} \mathrm{C}$ was recorded in Pecora in July 1997). Interestingly, this exceptionally cool June in 2003 was also exceptionally hot (and the hottest in the study period) in Western Europe, including in the south-western tip of the study area (e.g. the anomalies of $+4{ }^{\circ} \mathrm{C}$ in Vienna and $+4.6{ }^{\circ} \mathrm{C}$ in Zagreb).

\section{Conclusion}

Extremely cool summer months and seasons were defined as having an average air temperature two standard deviations $\left(\mathrm{t} \leq \mathrm{t}_{\mathrm{av}}-2 \sigma\right)$ lower than the respective long-term value. The study covered 59 weather stations in Central and Eastern Europe during the period 1951-2010. Cool summers (ECS) so defined were only limited to some distinct parts of the area, including its northern sections (from an area north of approximately $55^{\circ} \mathrm{N}$ southwards with the greatest southern extent in the Central Russian Upland); in the southwest (in the Ore Mountains, Sudeten and Carpathian Mountains and their environs); and on the lower Volga river and the Russian-Kazakh borderland. Exceptionally cool summers were observed at 34 of the 59 stations included in the study (58\%) no more than two times during the period.

Detailed analysis only included ECSs observed at three stations (5\% of the total stations) or more. Six such seasons were identified (1962, 1969, 1976, 1978, 1984 and 1994), which was exactly one half of the number of exceptionally hot seasons (12).

The small overall number of exceptionally cool summer seasons during the study period caused their occurrence pattern to display only weak correlation with the progressively increasing summer temperatures observed (especially in the western parts of the area), as opposed to the clearly increasing number of exceptionally hot summer months and seasons. Indeed, no extremely cool summer was observed during the decade 2001-2010, when the number of exceptionally hot summers was the greatest (5), and there were no ECS during 1951-1960, when there were no exceptionally hot summers either. 


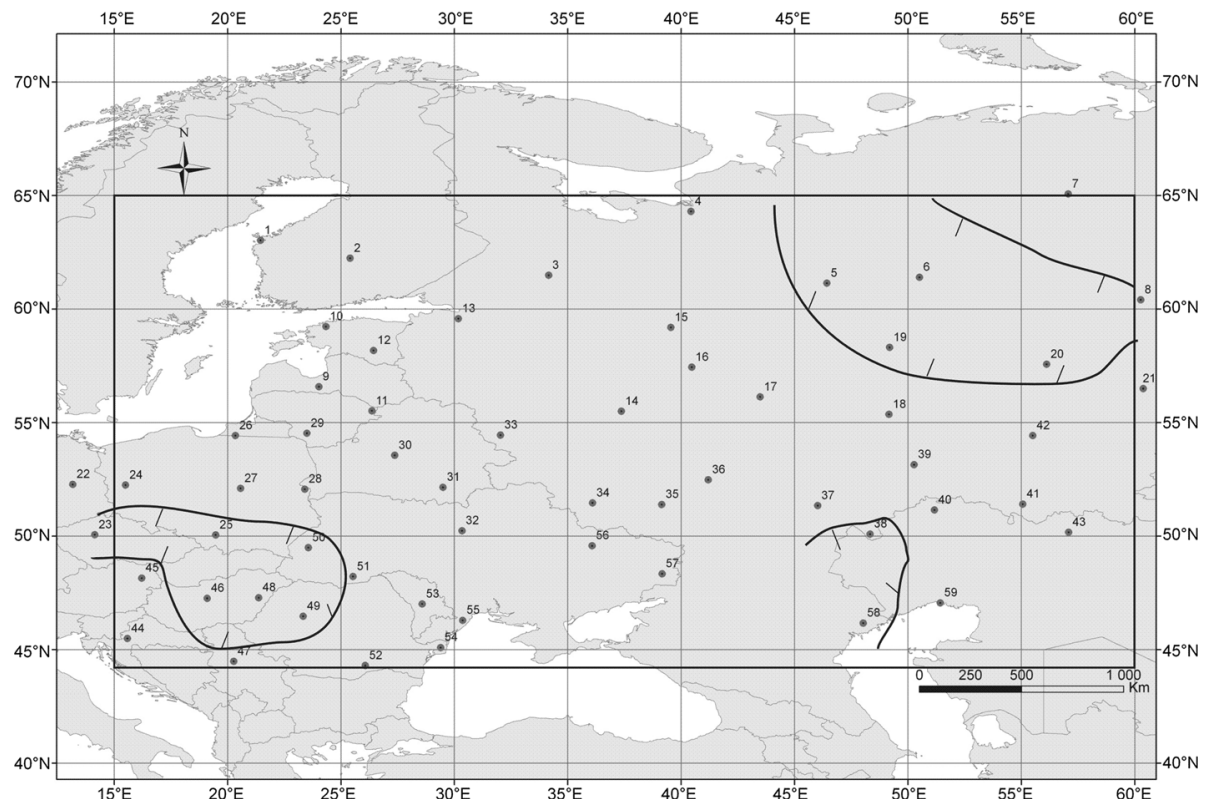

Fig. 5 ECS coverage in 1978

The warming effect, observed in the western part of the study area (Twardosz and Kossowska-Cezak 2013a) is accompanied by both an ever more frequent occurrence of exceptionally hot summers and a decline in the number of exceptionally cool summers, even though that latter effect is less pronounced due to a lower overall frequency of ECSs.

It could also be argued that the contemporary warming effect involves an increase in the temperature fluctuation observed not just in the frequency of exceptional summer seasons, but also of individual months and their temperature anomalies. In the beginning of the 60 -year study period, exceptional temperature seasons did not occur and exceptional months were few and far between, while during the last decade there are both hottest and coolest months of the entire periods with anomalies of $5{ }^{\circ} \mathrm{C}$ and more. During the twentyfirst century, there also occurred a case where the same month (June 2003) was extremely hot and extremely cold ( 7 and 11 stations, respectively) in different large parts of the study area.

The average air temperature of an exceptionally cool summer was normally lower than the long-term average by $2-3{ }^{\circ} \mathrm{C}$ (with just two cases of $3.1^{\circ} \mathrm{C}$; the monthly anomalies were greater). An anomaly of a similar magnitude occurred during the extremely cool and wet summer of 1816 in Western Europe. ECS could include an exceptionally cool month, but in most cases $(58 \%)$ the exceptionally low average temperature of the season was a result of a long persistence of relatively low temperatures in all summer months (below the long-term average, but above the threshold value $\mathrm{t} \leq \mathrm{t}_{\mathrm{av}}-2 \sigma$ ). For this reason, no single exceptionally cool summer can be identified as the coolest.

During extremely cool summers, the temperatures most harmful to human health (on days with a maximum temperature $>30{ }^{\circ} \mathrm{C}$ and with minimum temperatures $>20^{\circ} \mathrm{C}$ ) were virtually unrecorded (isolated cases along the southern edge of the area) and days with a maximum temperature $>25{ }^{\circ} \mathrm{C}$ were much less frequent than average. 
Extremely cool summers are not regarded as an extreme phenomenon, especially in recent years when they have nearly disappeared. It seems, however, that they deserve attention precisely because of their rarity.

Open Access This article is distributed under the terms of the Creative Commons Attribution License which permits any use, distribution, and reproduction in any medium, provided the original author(s) and the source are credited.

\section{References}

Anisimov OA, Borzenkova II, Zhil'tsova EL, Zakharova OK, Kokorev VA, Reneva SA, Strel'chenko YuG (2011) Hydrometeorological conditions of the Volga Region and current climate changes. Russ Meteorol Hydrol 36(5):307-314

de Freitas CR (2003) Tourism climatology: evaluating environmental information for decision making and business planning in the recreation and tourism sector. Int J Biometeorol 48:45-54

Elizbarashvili ESh, Meskhiya RSh, Elizbarashvili ME (2007) Dynamics of occurrence frequency of extreme anomalies of monthly mean air temperature in Georgia in the 20th century and its effect on precipitation and on the river water discharge. Russ Meteorol Hydrol 32(1):71-74

Filipiuk E, Kaszewski BM (2000) Hot and cold summer in Central Europe (1871-1990). Prace Geograficzne 108:149-154

Gerstengarbe FW, Werner PC (1992) The time structure of extreme summers in Central Europe between 1901 and 1980. Meteorol Z 1:285-289

International Meteorological Vocabulary (1992) WMO, No. 182, Geneva

Isayev AA, Sherstyukov BG (2008) Mean and extreme characteristics of Moscow climate at the end of the 20th century. Russ Meteorol Hydrol 33(3):151-158

Jaagus J (2006) Climatic changes in Estonia during the second half of the 20th century in relationship with changes in large-scale atmospheric circulation. Theo Appl Climatol 83:77-88

Kossowska-Cezak U (1997) Miesięczne warunki termiczno-opadowe i ich zależność od cyrkulacji atmosferycznej. Prace i Studia Geograficzne 20:125-144

Kossowska-Cezak U, Twardosz R (2012a) Niezwykle gorące miesiące i sezony letnie w Europie Środkowej i Wschodniej (1951-2010). Cz. I Niezwykle Gorące Miesiące Letnie. Przegląd Geofizyczny 3-4:299-324

Kossowska-Cezak U, Twardosz R (2012b) Niezwykle gorące miesiące i sezony letnie w Europie Środkowej i Wschodniej (1951-2010). Cz. II Niezwykle Gorące Sezony Letnie. Przegląd Geofizyczny $3-4: 325-342$

Kuziemska D (1975) Opady atmosferyczne chłodnych, umiarkowanych i ciepłych miesięcy roku (na przykładzie Warszawy). Temat 1.05.04, Problem 157, IMGW, 1-28

Piervitali E, Conte M, Colacino M (1997) Summer air temperature anomalies in Europe during the century 1811-1910. Nuovo Cimento Della Società Italiana di Fisica 20:195-208

Scott D, Lemieux C (2010) Weather and climate information for tourism. Proc Environ Sci 1:146-183

Sidorenkov NS, Orlov IA (2008) Atmospheric circulation epochs and climate changes. Russ Meteorol Hydrol 33(9):553-559

Slonosky VC, Jones PD, Davies TD (2001) Atmospheric circulation and surface temperature in Europe from the 18th century to 1995. Int J Climatol 21:63-75

Trigo RM, Vaquero JM, Alcoforado MJ, Barriendos M, Taborda J, Garć1a-Herrera R, Luterbacher J (2009) Iberia in 1816, the year without a summer. Int J Climatol 29:99-115

Twardosz R, Kossowska-Cezak U (2012) Exceptionally hot summers in Central and Eastern Europe (1951-2010). Global Conference on Global Warming 2012, Book of Abstract, July 8-12, 2012, Istanbul Technical University (ITU), Istanbul, Turkey

Twardosz R, Kossowska-Cezak U (2013a) Exceptionally hot summers in Central and Eastern Europe (1951-2010). Theo Appl Climatol 112:617-628

Twardosz R, Kossowska-Cezak U (2013b) Exceptionally hot summers months in Central and Eastern Europe during the years 1951-2010. In: I Dincer, C Ozgur Colpan, F Kaglioglu (eds) Causes, Impacts and Solutions to Global Warming. Springer, 17-35

Twardosz R, Niedźwiedź T, Łupikasza E (2011) Zmienność i uwarunkowania cyrkulacyjne występowania postaci i typów opadów atmosferycznych na przykładzie Krakowa. Wydawnictwo UJ, Kraków

WMO (1996) Climatological normals (CLINO) for the period 1961-1990. Geneva, 1996, WMO 
Yu Bardin M (2007) Anticyclonic quasi-stationary circulation and its effect on air temperature anomalies and extremes over western Russia. Russ Meteorol Hydrol 32(2):75-84

Zveryaev II (2007) Climatology and long-term variability of the annual cycle of air temperature over Europe. Russ Meteorol Hydrol 32(7):426-430 